\title{
BABYLONIAN TEXTS FROM THE FOLIOS OF SIDNEY SMITH PART FOUR: TWO OLD BABYLONIAN LETTERS
}

BY

Andrew R. GEORGE

The late Sidney Smith's folios of cuneiform copies and notes contained copies of several Old Babylonian and Neo-Babylonian archival texts that remained unpublished at the time of his death in 1979. In all cases but one, these tablets have been either published by other scholars or Smith's copy has been found to be incomplete. The purpose of this article is to make available to scholarship the single exception and thereby finally to complete the publication of Smith's copies of cuneiform texts. ${ }^{1}$ The exception is an Old Babylonian letter (no. 1). Alongside it is presented Smith's copy of another Old Babylonian letter that has been made public but not previously published in cuneiform (no. 2).

\section{THE DEARE TABLET}

In the summer of 1941, while Keeper of Egyptian and Assyrian Antiquities at the British Museum, Sidney Smith received for study a small cuneiform tablet sent by the municipal museum in Littlehampton, Sussex. He identified it as an Old Babylonian letter, copied it and had it photographed by the British Museum photographic service (Figs. 1-2). According to the British Museum's records the photographic negatives bear the numbers H.243-246; it was further noted that the tablet belonged at the time to a lady identified as E. Winifred Deare of Worthing, also in Sussex.

In due course Smith returned the tablet to the curator of Littlehampton Museum, along with a letter expressing a desire to publish it and asking permission from its owner to do so (Smith folios, handwritten copy 18.vi.1941). No reply is extant, only a postcard confirming the safe return of the tablet to Littlehampton and advising that the museum was closed for the duration of the war (Smith folios, 25.vii.1941). Smith never did publish his copy and the museum authorities can find no trace of the tablet in their records. ${ }^{2}$ Because its whereabouts today are unknown, the tablet will have to go by the name of the Deare tablet.

The Deare tablet is inscribed with a short letter in Old Babylonian cuneiform and endorsed with the sender's cylinder seal. In his letter to his colleague in Littlehampton Smith identified the tablet as a "complete envelope with a letter inside". He may have assumed that it was an envelope simply from the presence of the seal impressions. Dominique Charpin points out to me that an envelope bearing the full text of a letter would be extraordinary, but that there are known examples of Old Babylonian letters on tablets endorsed with sealings (discussed by

1. See previously George 1988, 1991, 2004, 2006. Smith's copies of a few Old and Neo-Assyrian archival documents are presented in George 2010.

2. I thank Lucy Ashby, Archives and Exhibitions Officer of the Littlehampton Museum for her assistance in this matter. 
Kraus 1985a). On these grounds it may be suspected that the Deare tablet is not after all a tablet enclosed in an envelope, as Smith presumed, but solid; verification must await the tablet's reappearance.

Whether tablet or envelope, the photographs show that the object measures $34 \times 34 \times$ $20 \mathrm{~mm}$. The content of the letter written on it is a simple instruction: Damiq-Marduk orders Marduk-dayyān to give a quantity of bricks to Eliyātum, and advises him that Eliyātum will repay him in kind at the beginning of the following year. Damiq-Marduk's sealing commits him as a guarantor of this obligation, and demonstrates that Eliyātum was acting as his agent. There is one point of philological interest (see 1.10 and the note thereon).

obv.

$1 \quad a-n a{ }^{\mathrm{d}} \operatorname{marduk(amar.utu)-dayyān(di.kud)} q i \operatorname{i} b i-m a$

2 um-ma da-mi-iq- ${ }^{\mathrm{d}}$ marduk(amar.utu)-ma

32 mušar(sar) libnātim $\left(\mathrm{sig}_{4}\right)^{\text {bá }}$

4 a-na e-li-ia-tum $\{i-[d i-i n-m] a\}$

$5 \quad i$-di-in-ma

rev.

$6 \quad$ wa-ar-ka-nu

$7 \quad \operatorname{libnātim}\left(\mathrm{sig}_{4}\right)^{\text {bá }} k i-m a$ libnātim $\left(\operatorname{sig}_{4}\right)^{\text {bá }}$

$8 \quad$ i-na pa-ni ša-at-tim

9 ú-ta-ar

$10 \quad a$-wi-lum be-el și-「bu!-tim!?

edge

$11 \quad \operatorname{libnātim}\left(\operatorname{sig}_{4}\right)^{\text {bá }} l a ~ t a-k a-/ a l-l a-\left[\check{s} u^{\top}\right.$

$12 \quad$ erasure\}

${ }^{1}$ To Marduk-dayyān say, ${ }^{2}$ thus Damiq-Marduk: ${ }^{5}$ give ${ }^{3}$ two mušarum-measures of bricks ${ }^{4}$ to Eliyātum and ${ }^{6}$ later, ${ }^{8}$ at the beginning of the year, ${ }^{9}$ he will return them, ${ }^{7}$ brick for brick. ${ }^{10}$ The fellow is conducting a business enterprise; ${ }^{11}$ do not withhold the bricks from him.

seal inscription

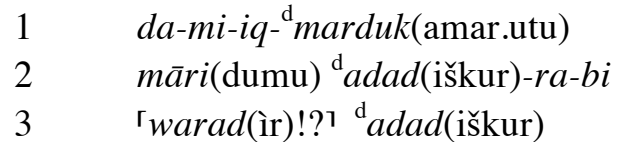

Damiq-Marduk, son of Adad-rabi, servant(!) of Adad.

Notes

3. In the Old Babylonian period 2 mušar of volume comprised 288 cubic cubits, the equivalent of about $36 \mathrm{~m}^{3}$ (Powell 1989-90: 490). In her study of the metrology of bricks Eleanor Robson reports that the volume measure mušarum effectively functioned as a numerical term, with a value 720 bricks (Robson 1999: 59). Thus Damiq-Marduk asks Marduk-dayyān to give Eliyātum 1,440 bricks.

4. The word idinma was erased and written on the next line instead.

10. The last word of this line is written over the junction between face and edge, and its legibility suffers as a consequence. Although Smith's copy suggests otherwise, the final sign appears from the photograph to end with a horizontal wedge, not a vertical. Given the traces, 
there is good reason to suspect the presence of the term bēl sibutim, a compound booked in the Old Babylonian lexical list OB $L u$ B ii 52 (ed. Civil 1969: 180): 'lú.al.áš`.a = 'bél-el șibu!(MU)-tim; see also vi 35 (ed. Civil 1969: 186): [lú]! ‘á.áš.a = $a$-wi-il și-bu-t[im].

Because șibûtum can mean "need, desire", the dictionaries both interpret bēl șibûtim and awīl sibûtim, lit. "owner/man of ș.", as a person needed by some other party $(C A D-171$ "needed person", $A H w 1099$ "benötigte Person"). F. R. Kraus adopted the same position in his study of bèl compounds in Old Babylonian (1973: 80: "jemand, den man braucht", "nach dem Bedarf besteht"; cf. pp. 82, 89, ref. courtesy D. Charpin). In addition to the lexical evidence there are two passages in other Old Babylonian letters that use the phrases: (a) TCL VII 51: 17-19 (ed.

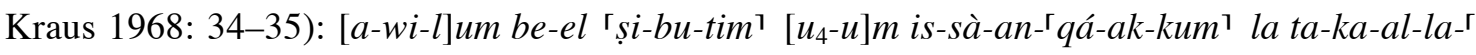
$a-\check{s} u$ " "the fellow is a bēl ș.: when he comes to you do not detain him"; (b) VAS XVI 57: 9-10 (ed. Frankena 1974: 36-37): a-wi-lum ša aš-pu-ra-ak-kum a-wi-il și-bu-tim la ik-ka-al-lam "the fellow I have sent you is an awīl s.; he must not be kept from me". It is easy to see that the dictionaries' understanding of $b \bar{e} l$ and awīl șibuttim works well here, for in both passages the sender has a vested interest in the speedy return of an indispensable go-between. Consequently neither Kraus nor Frankena dissented from the dictionaries' consensus in their respective translations. However, a vested interest is not a good motive in the present letter, where the sender does not ask for the immediate return of Eliyātum, merely for the latter to be given bricks without delay. The conventional understanding of bēl șibûtim here stalls on a non sequitur.

The word sibûtum is much used in the Old Babylonian period to mean "business activity", "enterprise". If the sibûtum in $b \bar{e} l$ and aw̄ șibûtim applies to the man so described and not to another party (who needs him), the phrases would then denote a person doing business. Passages (a) and (b) make equally good sense if the phrases are so translated: (a) "the fellow is conducting a business enterprise: when he comes to you do not detain him"; (b) the fellow I sent you is engaged on business; he must not be withheld from me". The present passage only makes sense on such an understanding: Eliyātum is a busy man engaged on a serious purpose and should not be refused what he has come to fetch.

11. Final - $\breve{s} u$ lacks mimation, for it is dative, in ablative meaning; for kalûm + dative in other Old Babylonian letters see the passage VAS XVI 57: 9-10 quoted in the note on 1. 10, and two further instances:

(a) In Sippar a certain Māri-Ištar instructed his correspondents (CT 33 26a 6-10, ed. Frankena 1966: 116-17 no. 182): ${ }^{\mathrm{m}}$ šum-ma-la- ${ }^{\mathrm{d}}$ marduk(amar.utu)-ma-an-ni țup-pí uš-ta-bi-la-ak-ku-nu-

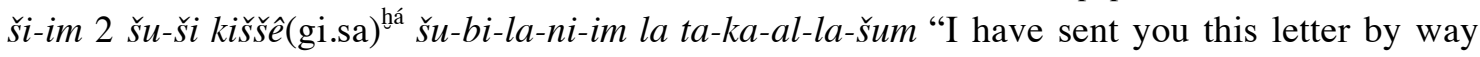
of Šumma-lā-Marduk-mannī. Have him bring me twice sixty reed bundles. Do not withhold (any) from him!"

(b) At Mari the lady Bahlatum grew impatient for the jewellery she had ordered (ARM X 109: 17-19, ed. Durand 2000: 409-11 no. 1209): ši-ip-ra-am ša-a-「tu ar $\left.{ }^{\top}-h i-i s ̌ s ̌ u-b i-l a m ~ l a ~ ` t a\right\urcorner-k a-$ $l a-a[m]$ "Send me that piece of work very soon! Do not keep it from me!"

Seal impression. Impressions of cylinder seals are often difficult to extract from the background surface when they share it with writing. The traces Smith copied at the beginning of 1.3 do not suggest any obvious reading; they could well stem from the collation of two different impressions. The impression of a seal of a Damiq-Marduk, son of Adad-rabi, occurs between two other impressions on the lease contract BIN VII 182, where it records the presence of the witness da-mi-iq- ${ }^{\mathrm{d}} m \operatorname{arduk(amar.utu)}$ (1. 27) and reads: [d]a-mi-iq- ${ }^{\mathrm{d}} m$ [ $\operatorname{arduk(\mathrm {amar}.utu)]~/~}$ $m \overline{a r i}$ (dumu) ${ }^{\mathrm{d}} a d a d$ (iškur)-ra-[bi] / warad(ìr) ${ }^{\mathrm{d}} a$ [dad(iškur)] "Damiq-Marduk, son of Adad-rabi, servant of Adad". I propose that this is the same seal as that used on the Deare tablet. 


\section{Commentary}

The letter's spelling is not diagnostic of a provenance more exact than southern Mesopotamia, but the presence of two personal names compounded with Marduk, the god of Babylon, suggests that it derives from northern Babylonia. In fact, Damiq-Marduk's seal inscription almost certainly duplicates the second of three seal impressions that endorse a tablet now in New Haven, NBC 5290 (BIN VII 182 = Alexander 1943 pl. 60, ed. Cocquerillat 1967: 173; seal quoted in the textual note above). In that tablet, which is dated to the fourth year of king Samsuiluna of Babylon, Damiq-Marduk, son of Adad-rabi, is one of the witnesses to Marduk-dayyān's contractual agreement to rent and manage a date-plantation.

The Damiq-Marduk and Marduk-dayyān of the contract BIN VII 182 may well be the same persons as the sender and addressee of the letter published here. If so, the letter's archival context begins to emerge, for BIN VII 182 is one of a small group of tablets, without archaeological provenance and scattered among collections in Europe and North America, that is concerned with the agricultural affairs of a group of tribesmen and the settlement named after

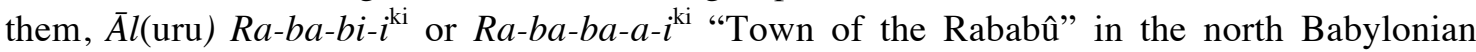
province of lower Yahrurum, in Samsuiluna's reign. This archive and its connections have been reported by, among others, Marten Stol (1976: 86, 1982: 162, 2004: 819, 2007), Dominique Charpin and Jean-Marie Durand (1981: 27, Charpin 1981: 521 A8) and Denis Lacambre (1998: 136-37, ref. courtesy Charpin). The dossier, in so far as it concerns Damiq-Marduk, Mardukdayyān and the Rababû, is here set out in tabular format (Table 1). ${ }^{3}$

As can be seen from the table, a person or persons called Marduk-dayyān plays a prominent part in this dossier. In five documents Marduk-dayyān takes out a lease on agricultural land: three date-plantations of the Rababû (texts Nos. 1, 4 and 5) and two fields (Nos. 7 and 9), at least one for the purpose of growing garlic (No. 7). Four documents of the group list a Marduk-dayyān as a witness, either described as a date-farmer (nukaribbum, Nos. 2 and 8 in the table), or as a son of Adad-rabi (Nos. 1 and 3). In text No. 1 two persons of this name appear, Marduk-dayyān as lessee of a date-grove (i.e. the date-farmer) and Mardukdayyān, son of Adad-rabi, as witness, so it becomes unlikely that the two are the same individual.

Damiq-Marduk, son of Adad-rabi, is presumably a brother of the Marduk-dayyān who shares his patronym. He acts as a witness to one of the Marduk-dayyāns' leases (No. 4). In one of the leases where the date-farmer Marduk-dayyān is himself a witness, a certain ${ }^{\mathrm{md}}$ asal.lú.he$\mathrm{sa}_{6}$.ga agrees terms to rent plots of arable land (No. 8); it seems likely that this person is our Damiq-Marduk, under a Sumerianized form of his name ( ${ }^{\mathrm{d}}$ asal.lú.he $=$ Marduk, sa 6 .ga $=$ damiq) . The Adad-rabi who appears fifteen years later as a lessee of a Rababaean date plantation (Nos. 10-11) is unlikely to be the father of either Damiq-Marduk, son of Adad-rabi, or Mardukdayyān of the same patronym, given the lapse of years, but the name could well have been borne by one of their sons, i.e. a grandson of Adad-rabi Senior. In taking out a lease on a dategrove of the Rababû, Adad-rabi Junior would be continuing the family's business practices. Text No. 12, undated, documents a further commercial relationship between men called Marduk-dayyān and Damiq-Marduk, in a transaction concerning the barter of garlic in which the former probably figures as producer (cf. No. 7), the latter as one of four traders.

3. The date-grove lease TIM V 40 ([n].iii.Si 26) is associated with this archive by Stol 1982: $162 \mathrm{n} .3$ but is omitted here because it features neither Damiq-Marduk, Marduk-dayyān nor the Rababû. 
Table 1. Documents attesting to the activities of persons named Damiq-Marduk and

Marduk-dayyān and/or to land belonging to the Rababû, in order of date.

$\mathrm{Si}=$ Samsuiluna

Text Publication

Description and date

$1 \quad$ BIN II $77=$ Nies and Keiser 1920 pl. 34, cf. Cocquerillat 1967: 174

Marduk-dayyān leases a date-grove of the Rababû from Adad-šarrum and Šunūma-ilū.

Marduk-dayyān, son of Adad-rabi (seal), is a witness. 20.ix.Si 2

2 AO 10340, Nougayrol 1979: 75, ed. Charpin and Durand 1981: 29

Šamaš-nāṣir leases a date-grove of the Rababû from Adad-šarrum, Šunūma-ilū and others. Marduk-dayyān nukaribbum is a witness. 1.xii.Si 2

3 Ex coll. S. Gregory, ed. Langdon 1934, Cocquerillat 1967: 186

Ibbatum leases a date-grove from Adad-šarrum, Šunūma-ilū and others. Mardukdayyān, son of Adad-rabi (seal), is a witness. 10.xii.Si 3

$4 \quad$ BIN VII 182 = Alexander 1943 pl. 60, ed. Cocquerillat 1967: 173

Marduk-dayyān leases a date-grove of the Rababû from Qurrudum and others. DamiqMarduk, son of Adad-rabi (seal), is a witness. 24.xi.Si 4

$5 \quad$ YOS XII $126=$ Feigin 1979 pl. 23

Marduk-dayyān leases a date-grove of the Rababû from Qurrudum, Adad-šarrum, Šunūma-ilū and others. 5.i.Si 5

6 AO 10333, Nougayrol 1979: 73, ed. Charpin and Durand 1981: 27-29

Maškum leases a plot of arable land of the Rababû from Adad-šarrum, Šunūma-ilū and others. -.iii.Si 5

$7 \quad$ YOS XII $135=$ Feigin 1979 pl. 24

Marduk-dayyān leases a field from Nabium-mālik to grow garlic. 20.iv.Si 5

$8 \quad$ YOS XII 217= Feigin $1979 \mathrm{pl} .40$

Asalluhe-saga (= Damiq-Marduk) leases arable land from Šunūma-ilū and MāriSilakkum. Adad-šarrum and Marduk-dayyān nukaribbum are witnesses. -.iii.Si 7

$9 \quad T L B$ I $205=$ Leemans $1954-64$ pl. 57

Ipqatum and Marduk-dayyān lease arable land from Wēdum-qarrād. [Šamaš]-nāṣir is a witness. Date 1.v.Si 8

10 Grant 1938: 242-43 no. 9, cf. Cocquerillat 1967: 175

Adad-rabi and Iddin-ilum lease a date-grove of the Rababû from Šunūma-ilū and others. 15.x.Si 23

11 YOS XII $434=$ Feigin 1979 pl. 76, duplicate of no. 10

12 BJ 91, ed. Ungnad 1925: 95-98, cf. Stol 1982: 162 n.3

Marduk- ${ }^{-}$dayyān(di.kud) ${ }^{1}$ is noted as liable to make a balancing payment, arising from the barter of 180 strings of garlic ( $g i-i d-l u^{\top}$ sum $^{\text {sar }}$ ), to four individuals, including Damiq-Marduk. Undated

13 Deare tablet, figs. 1-2

Damiq-Marduk, son of Adad-rabi, sends a message to Marduk-dayyān regarding bricks. Undated 


\section{THE RAPHAEL TABLET (ABB X 144)}

Smith's copy of a second Old Babylonian tablet is accompanied by an annotation in his hand, "Old Babylonian letter (collection of O. C. Raphael Esq.)". Oscar Raphael was a collector of Asian art and antiquities who became honorary keeper of Oriental ceramics at the Fitzwilliam Museum, Cambridge, in 1926. ${ }^{4}$ His collection comprised mainly Far Eastern and Islamic sculpture, jade and ceramics, but also some Egyptian and ancient Persian antiquities (Gray 1945), including a serpentine head of the twelfth-dynasty pharaoh Amenemhet III (Ricketts 1917). On his death in $1941 \mathrm{Mr}$ Raphael bequeathed his treasures partly to the Fitzwilliam and partly to the British Museum, in a division designed to strengthen each museum's holdings. ${ }^{5}$ His Babylonian tablet was unsurprisingly deemed surplus to the requirements of the British Museum and entered the Fitzwilliam in 1946, where it now goes by the accession number 42-1946. Smith must have copied it in the 1920s or '30s (Fig. 3).

The letter is addressed to a woman called Kapazila by her brother Sîn-erībam and concerns a strategy for buying her release from bondage. Its text was published, alongside six other Old Babylonian letters in the Fitzwilliam Museum, by F. R. Kraus in vol. 10 of Altbabylonische Briefe (Kraus 1985b: 126-27 no. 144). Smith and Kraus disagree on two points. In 1. 13 Smith has copied, after $i$-li-ka-ki, a further sign, obviously written on the right edge, which Kraus correctly placed in 1. 6, where it is the har in the personal name ${ }^{\mathrm{m}} n u$-úr- ${ }^{\mathrm{d}} e{ }^{-}-$ har-ra. In 1. 18 Smith copied $l i-t i(\mathrm{TI})-b u-u ́ u$ where Kraus inadvertently transliterated li-ti-bu-ú. The troublesome 1. 7, which Kraus noted as marred by erasure and failed to decipher, can plausibly be read from Smith's copy as ma!-la ti-še!-e. The sentence that includes this clause then translates (11. 6-11): "Your heir, Nūr-Išhara, has taken all you possess (mala tǐšê) from your house, and your chest is in store at Warad-[DN]'s house."

4. See the Fitzwilliam Museum's webpage at http://www.fitzmuseum.cam.ac.uk/gallery/

cockerell/

pigstytopalace/orientalceramics.html (visited April 2009).

5. The division of the collection is described in detail by Gray 1945, but see also the Cornucopia website managed by a British organization called the Museums Libraries and Archives Council, http://www .cornucopia.org.uk/html/search/verb/GetRecord/8387 (visited April 2009). 

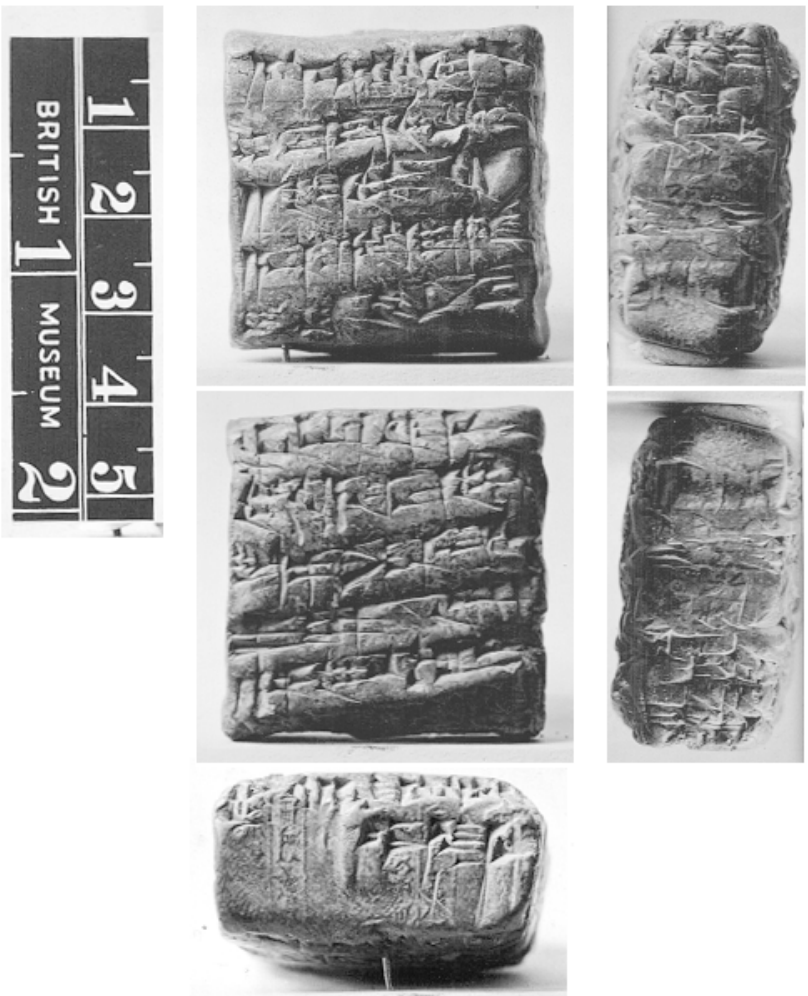

Fig. 1. Tablet formerly in the possession of E. Winifred Deare, obverse, reverse, right and top edges. Photographs courtesy of the Trustees of the British Museum

$$
\text { obv. }
$$

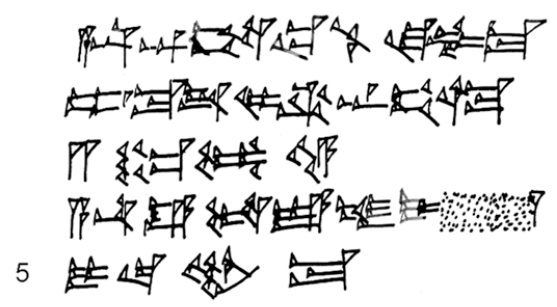

rev.

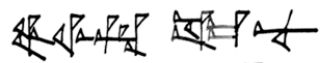

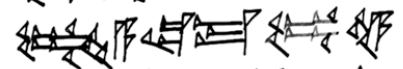

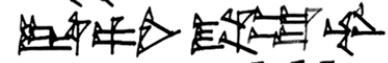

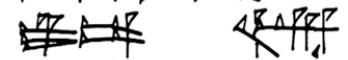

10

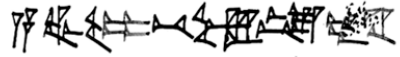

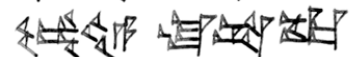

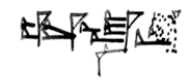

seal inscription

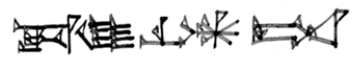

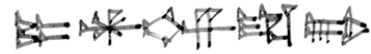

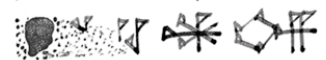

Fig. 2. Sidney Smith's hand copy of the Deare tablet

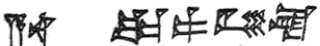

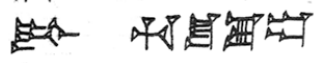 \\ 通紫的企

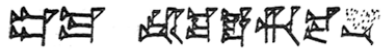

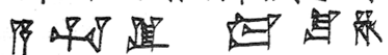

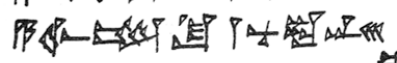

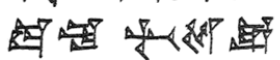

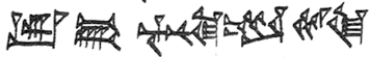

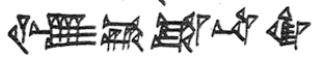

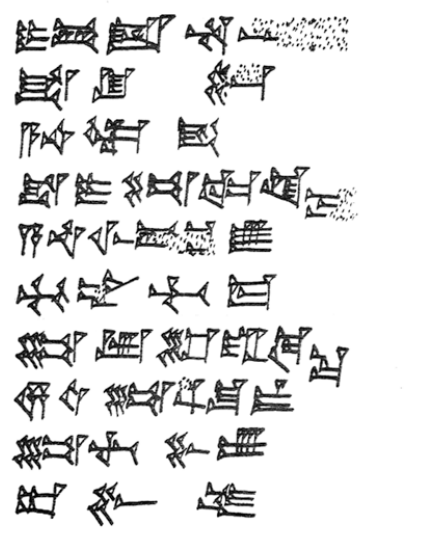

Fig. 3. Sidney Smith's hand copy of the Raphael tablet (= AbB X 144) 


\section{BIBLIOGRAPHY}

Alexander, J. B. 1943. Early Babylonian Letters and Economic Texts. Babylonian Inscriptions in the Collection of J. B. Nies 7. New Haven, Conn.

Charpin, D. 1981. La Babylonie de Samsu-iluna à la lumière de nouveaux documents. Bibliotheca Orientalis 38, 56: $517-47$

Charpin, D. and J.-M. Durand 1981. Textes paléo-babyloniens divers du Musée du Louvre. Revue d'Assyriologie 75: $15-29$

Civil, M. 1969. The Series lú $=\check{s} a$ and Related Texts. Materials for the Sumerian Lexicon 12. Rome

Cocquerillat, D. 1967. Aperçus sur la phéniciculture en Babylonie à l'époque de la Ière dynastie de Babylone. Journal of the Economic and Social History of the Orient 10, 2-3: 161-223

Durand, J.-M. 2000. Documents épistolaires du palais de Mari 3. Paris

Feigin, S. I. 1979. Legal and Administrative Texts of the Reign of Samsu-iluna. Yale Oriental Series, Babylonian Texts 12. New Haven, Conn.

Frankena, R.

1966. Briefe aus dem British Museum (LIH und CT 2-33). Altbabylonische Briefe 2. Leiden

1974. Briefe aus dem Berliner Museum. Altbabylonische Briefe 6. Leiden

George, A. R.

1988. Babylonian texts from the folios of Sidney Smith, Part one. Revue d'Assyriologie 82: 139-62

1991. Babylonian texts from the folios of Sidney Smith, Part two: Prognostic and diagnostic omens. Revue d'Assyriologie 85: 137-67

2004. Royal inscriptions from the folios of Sidney Smith. Pp. 137-44 in From the Upper Sea to the Lower Sea: Studies on the History of Assyria and Babylonia in Honour of A. K. Grayson, ed. G. Frame. Leiden

2006. Babylonian texts from the folios of Sidney Smith, Part three: A commentary on a ritual of the month Nisan. Pp. 173-86 in If a Man Builds a Joyful House.... Studies in Honor of Erle Verdun Leichty, ed. A. Guinan et al. Cuneiform Monographs 31. Leiden

2010. Assyrian texts in the folios of Sidney Smith. Pp. 153-158 in Studies in Honor of Veysel Donbaz. DUB.SAR E.DUB.BA.A Veysel Donbaz'a Sunulan Yazilar, ed. S. Dönmez. Istanbul

Grant, E. 1938. Ten Old Babylonian contracts. Pp. 225-45 in The Haverford Symposium on Archaeology and the Bible, ed. E. Grant. New Haven, Conn.

Gray, B. 1945. The Oscar Raphael Collection for the nation. The Burlington Magazine for Connoisseurs 87 no. 512

Kraus, F. R. (Nov. 1945) 276-83

1968. Briefe aus dem Archive des Šamaš-hāzir in Paris und Oxford. Altbabylonische Briefe 4. Leiden

1973. Vom mesopotamischen Menschen der altbabylonischen Zeit und seiner Welt. Amsterdam

1985a. Altbabylonische Briefe mit Siegelabrollungen. Pp. 137-45 in Miscellanea Babylonica. Mélanges offerts à Maurice Birot, ed. J.-M. Durand and J.-R. Kupper. Paris

1985b. Briefe aus kleineren westeuropäischen Sammlungen. Altbabylonische Briefe 10. Leiden

Lacambre, D. 1998. Canaux paléo-babyloniens: le dossier du canal Ūbil-nuhšam dans la province du Yahrurum inférieur. Pp. 133-46 in Changing Watercourses in Babylonia. Towards a Reconstruction of the Ancient Environment in Lower Mesopotamia. Mesopotamian History and Environment Memoirs 5,1 , ed. H. Gasche and M. Tanret. Ghent

Langdon, S. 1934. A Babylonian contract for the rent of a garden. Journal of the Royal Asiatic Society 1934: 556-59

Leemans, W. F. 1954-64. Old Babylonian Legal and Administrative Documents. Tabulae cuneiformae (cuneiformes) a F. M. Th. de Liagre Böhl collectae Leidae conservatae 1. Leiden

Nies, J. B. and C. E. Keiser 1920. Historical, Religious and Economic Texts and Antiquities. Babylonian Inscriptions in the Collection of J. B. Nies 2. New Haven, Conn.

Nougayrol, J. 1979. Tablettes diverses du Musée du Louvre. Revue d'Assyriologie 73: 63-80

Powell, M. 1989-90. Maße und Gewichte. Reallexikon der Assyriologie VII 5/6-7/8: 457-517

Ricketts, C. 1917. Head in serpentine of Amenemmes III in the possession of Oscar Raphael, Esq. Journal of Egyptian Archaeology 4: 211-12

Robson, E. 1999. Mesopotamian Mathematics 2100-1600 BC. Technical Constants in Bureaucracy and Education. Oxford Editions of Cuneiform Texts 14. Oxford

Stol, M.

1976. Studies in Old Babylonian History. Leiden 
1982. Review of Feigin 1979. Journal of the American Oriental Society 102: 161-63

2004. Wirtschaft und Gesellschaft in altbabylonischer Zeit. Pp. 643-975 in D. Charpin, D. O. Edzard and M. Stol, Mesopotamien. Die altbabylonische Zeit. Orbis Biblicus et Orientalis 160, 4. Fribourg and Göttingen

2007. Rababu. Reallexikon der Assyriologie XI 3-4: 209

Ungnad, A. 1925. Urkunden aus der Zeit des Reiches von Larsa und der Hammurabi-Dynastie. Zeitschrift für Assyriologie 36: 89-100

\section{RÉSUMÉ}

Dans cet article sont publiées les copies par le regretté Sidney Smith de deux lettres paléo-babyloniennes, la première étant accompagnée d'une édition commentée ; il s'agit de l'ordre de prêter une certaine quantité de briques à un tiers. Cette lettre a été envoyée par Damiq-Marduk à Marduk-dayyān, qui sont probablement les personnes de ce nom connues par leur implication dans la culture de palmiers de la région du Yahrurum inférieur pendant le règne de Samsu-iluna de Babylone. La lettre se signale par son emploi de l'expression akkadienne bēl șibûtim, que l'on propose ici de comprendre comme désignant un homme d'affaires.

\section{ABSTRACT}

This article publishes the late Sidney Smith's drawings of two Old Babylonian letters and gives an annotated edition of the first, an instruction to lend a quantity of bricks to a third party. It was sent by Damiq-Marduk to Mardukdayyān, who are probably the persons of these names known to have been engaged in date-cultivation in the province of lower Yahrurum during the reign of Samsuiluna of Babylon. The letter is noteworthy for its use of the Akkadian expression bēl șibûtim, here argued as denoting a person conducting business activities.

SOAS, University of London, Thornhaugh Street, London WC1H 0XG 